INFO ARTIKEL

Riwayat Artikel:

Diterima : 05 Mei 2018

Disetujui : 15 Agustus 2018

\title{
PENIDIDIKAN
}

\section{PENGARUH METODE PEMBELAJARAN RESITASI BERBASIS INFORMATION COMMUNICATION TECHNOLOGY (ICT) TERHADAP HASIL BELAJAR GEOGRAFI SISWA KELAS X IPS DI SMA NEGERI 1 PALEMBANG}

\author{
Ulfa Sari.NN', Murjainah ${ }^{2}$, Tobari ${ }^{2}$ \\ ${ }^{1}$ Bimbingan Belajar Primagama \\ ${ }^{2}$ Program Studi Pendidikan Geografi, Universitas PGRI Palembang

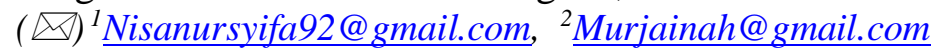

\begin{abstract}
ABSTRAK
Metode pembelajaran resitasi (penugasan) adalah metode penyajian bahan pembelajaran dimana guru memberikan tugas tertentu agar peserta didik melakukan kegiatan belajar. Metode Resitasi adalah cara untuk mengajar yang dilakukan dengan jalan tugas khusus kepada siswa untuk mengerjakan sesuatu diluar jam pelajaran. Tujuan dalam penenelitian ini adalah untuk mengetahui pengaruh metode pembelajaran Resitasi berbasis Information Communication Technology (ICT) terhadap Hasil Belajar Geografi Siswa Kelas X SMA Negeri 1 Palembang. Metode yang digunakan dalam penelitian ini yaitu metode penelitian eksperimen, dengan Design Quasi Eksperimen. Teknik pengumpulan data yang digunakan yaitu teknik observasi, dokumentasi dan tes. Hasil penelitian menunjukkan bahwa ada pengaruh metode pembelajaran resitasi berbasis ICT (Information Communication Technology) terhadap hasil belajar geografi pada siswa kelas X di SMA Negeri 1 Palembang. Hasil Resitasi kelas eksperimen dengan nilai rata-rata 75,71, hasil belajar kelas eksperimen dengan nilai rata-rata 84,28 dan hasil kelas kontrol dengan rata-rata nilai 65,4. Hal tersebut dapat dibuktikan dari analisis data yang menggunakan uji statistik aplikasi SPSS Versi 22 bahwa nilai $t_{\text {hitung }}=5,884$ lebih besar dari $t_{\text {tabel }}=1,69$ dengan taraf signifikansi 0,05 dimana t-hitung $>\mathrm{t}$-tabel $(5,884$ > 1,69). Maka Ho ditolak dan Ha diterima.
\end{abstract}

Kata kunci: Model Pembelajaran Resitasi Berbasis ICT, Hasil Belajar Siswa.

\section{PENDAHULUAN}

Pendidikan adalah suatu proses dalam rangka mempengaruhi siswa agar dapat menyesuaikan diri sebaik mungkin terhadap lingkungannya dengan demikian akan menimbulkan perubahan dalam dirinya yang memungkinkannya untuk berfungsi secara adekuat dalam kehidupan masyarakat. Sekolah merupakan lembaga pendidikan formal yang menyelenggarakan proses belajar mengajar, karena proses belajar mengajar dapat menghasilkan perubahan dalam diri seseorang, baik secara aktual maupun potensial. Disekolah terdapat banyak sekali mata pelajaran yang diajarkan kepada siswa, yang terdiri dari menulis, membaca, dan menghitung. Tidak hanya itu, ada juga mata pelajaran disekolah yang mengajarkan tentang gejala-gejala fenomena alam, mata pelajaran itu adalah Geografi. Geografi adalah ilmu tentang persamaan dan perbedaan fenomena geosfer dengan sudut pandang kewilayahan dan kelingkungan dalam konteks keruangan. Sejak manusia lahir di dunia, manusia 
sangat bergantung pada alam lingkungannya. Manusia membutuhkan alam untuk dapat memenuhi kebutuhan hidupnya. Inilah awal lahirnya studi geografi.

Untuk memperoleh pengetahuan, dalam pembelajaran geografi pada umumnya menggunakan kajian, sumber belajar, dan metode. Ada banyak metode pembelajaran dalam penyampaian materi, seperti metode ceramah, diskusi, demonstrasi, resitasi, eksperimental, studi tour dan lain-lain. Salah satu metode pembelajaran yang digunakan dalam pembelajaran geografi adalah metode resitasi. Metode pembelajaran resitasi adalah metode penyajian bahan dimana guru memberikan tugas tertentu agar peserta didik melakukan kegiatan belajar. Metode resitasi adalah penugasan yang diberikan guru kepada siswa untuk dikerjakan diluar jam pelajaran. Banyaknya kegiatan di sekolah dalam kaitannya dengan kegiatan pendidikan dan pengajaran, cukup menyita waktu siswa untuk melaksanakan kegiatan belajar mengajar tersebut. Untuk mengatasi keadaan ini guru harus memberikan tugas-tugas di luar jam pelajaran, sebab bila menggunakan seluruh jam pelajaran yang ada untuk setiap bidang studi tidak akan mencukupi tuntutan pelajaran yang diharuskan seperti yang tercantum dalam kurikulum. Oleh karena itu, dalam kurikulum 2013 disajikan tugas atau pekerjaan rumah sebagai pasangan atau pelengkap kegiatan tatap muka.

Untuk menyikapi permasalahan tersebut, metode pembelajaran resitasi atau metode pemberian tugas dirasa cukup efektif untuk mengatasi keterbatasan waktu tatap muka, karena metode resitasi ini merupakan salah satu metode pembelajaran yang menekankan kepada murid agar dapat belajar, menemukan dan merasakan sendiri kegiatan belajar yang dilakukan melalui pemberian tugas baik di dalam maupun di luar sekolah. Pemberian materi dan tugas dalam pembelajaran dapat menggunakan media-media pembelajaran.

Penerapan metode resitasi berbasis Information Communication and Technology dapat meningkatkan interaksi pembelajaran, mempermudah interaksi pembelajaran dimana dan kapan saja, memiliki jangkauan yang lebih luas, mempermudah penyempurnaan dan penyimpanan materi pembelajaran Fina (2010). Selama ini resitasi atau penugasan yang diberikan oleh guru hanya bersifat konvensional, akan tetapi adanya perkembangan teknologi ICT dengan perangkat lunak (Whatsapp) mampu menciptakan suasana belajar yang efektif karena memberikan kesempatan belajar lebih baik dan lebih cepat bagi siswa untuk memahami materi yang diajarkan, menampilkan tugas hingga diskusi antar siswa maupun bimbingan dengan pengajar seluruhnya dapat dikerjakan di luar jam pelajaran. Whatsapp merupakan aplikasi pesan untuk smartphone dengan basic blackberry messenger. Whatsapp adalah bagian dari sosial media yang sangat mungkin kita gunakan untuk bertukar pesan tanpa biaya sms, dikarenakan whatsapp messenger menggunakan paket data internet yang sama untuk e-mail, searching situs dan sebagainya. Dengan demikian, siswa dan guru bisa melakukan pembicaraan online, sharing File, bertukar foto, video, dan audio sehingga terjadi interaksi pembelajaran diluar jam pelajaran.

Hasil penelitian yang telah dilakukan oleh Fina Aryani menunjukkan bahwa penerapan resitasi dengan menggunakan grup Facebook dapat meningkatkan interaksi pembelajaran, mempermudah interaksi pembelajaran dimana dan kapan saja, memiliki jangkauan yang lebih luas, mempermudah penyempurnaan dan penyimpanan materi pembelajaran. Dari temuan ini dapat disimpulkan bahwa pembelajaran menggunakan grup sosial media Facebook dapat mempermudah interaksi pembelajaran. Tidak hanya facebook, belajar menggunakan sosial media Whatsapp juga bisa membantu dan mempermudah proses pembelajaran. Kemudian hasil penelitian yang telah dilakukan oleh Bagus Kurnia Wibisono menunjukkan bahwa efektivitas penggunaan grup Whatsapp mampu memberikan edukasi yang lebih baik dibandingkan menggunakan resitasi yang bersifat konvensional. Dari temuan ini dapat disimpulkan bahwa metode pembelajaran menggunakan grup Whatsapp berpengaruh posistif dan signifikan terhadap efektifitas belajar siswa.

Berdasarkan uraian di atas, penulis mengambil judul penelitian, "Pengaruh Metode Pembelajaran Resitasi Berbasis Information Communication Technology (ICT) terhadap Hasil Belajar Geografi Siswa Kelas X IPS SMA Negeri 1 Palembang, Tahun pelajaran 2018/2019. 


\section{Metode Pembelajaran Resitasi Berbasis ICT}

Pengertian metode pembelajaran resitasi (penugasan) adalah metode penyajian bahan dimana guru memberikan tugas tertentu agar peserta didik melakukan kegiatan belajar (Djamarah dan Zain, 2014). Metode pembelajaran resitasi (penugasan) berbeda dengan pekerjaan rumah (PR), resitasi (penugasan) dicirikan dengan pemberian tugastugas dimana materi dari tugas tersebut belum diajarkan dan resitasi (penugasan) ini dapat dikerjakan di kelas, di laboratorium, perpustakaan, bengkel, rumah, warnet/ internet atau dimana saja asal tugas tersebut dapat dikerjakan.

\section{Langkah-Langkah Penggunaan Metode Pembelajaran Resitasi}

Menurut Djamarah dan Zain, (2014). Langkahlangkah dalam penggunaan metode pembelajaran resitasi (penugasan) yaitu,

\section{1) Fase Pemberian Tugas}

Fase ini perlu dipertimbangkan apakah tujuantujuan, jenis tugas dan waktu yang diberikan untuk mengerjakan tugas tersebut haruslah jelas sehingga peserta didik dapat mengerjakan tugas dengan penuh tanggung jawab dan mereka tidak akan bertanya-tanya lagi apa yang harus mereka kerjakan dan apa yang menjadi tugasnya.

2) Fase Pelaksanaan Tugas.

Dalam proses ini pendidik harus membimbing dan mengontrol peserta didik apakah tugas dikerjakan dengan baik, apakah dikerjakan sendiri oleh peserta didik atau dikerjakan orang lain. Peserta didik juga dianjurkan untuk mencatat hasilhasil yang ia peroleh dengan baik dan sistematis dilanjutkan dengan membuat laporan dan powerpoint untuk diskusikan di kelas.

3) Fase Mempertanggung Jawabkan Tugas.

Apabila telah selesai melaksanakan atau mempelajari tugas, maka mereka harus membuat laporan, yang bentuknya telah ditentukan sesuai dengan tujuan tugas kemudian hasil tugas tersebut dipertanggung jawabkan di kelas melalui presentase. selanjutnya dapat berupa tanya jawab atau diskusi kelas.

\section{Langkah-Lagkah Pembelajaran ICT}

Suryani (2015), menyatakan bahwa langkahlangkah dalam mengelola dan menyajikan materi pembelajaran ICT sebagai berikut, a) Kumpulkan sumber yang memuat materi sesuai topik-topik yang akan diajarkan berdasarkan kurikulum atau kompetensi yang ingin dicapai.

b) Buat rancangan struktur (outline) media dan urutan penyajian materi serta bentuk interaksi sesuai dengan alur pembelajaran yang diharapkan. Bentuk-bentuk interaksi yang dapat dipilih antara lain; drill and practice, tutorial, permainan, (game), simulasi, eksplorasi, penemuan (discovery), dan pemecahan masalah (problem solving).

c) Pilih materi-materi yang sesuai dari sumbersumber yang terkumpul dan disajikan disetiap topik secara singkat dengan bahasa yang sederhana dan komunikatif, dilengkapi dengan ilustrasi/visualisasi dalam bentuk gambar, grafik, diagram, foto, animasi, atau audio-video.

\section{Hasil belajar Geografi}

Menurut Djamarah dan Zain, (2014). Hasil belajar yang menjadi indikator keberhasilan dalam suatu proses belajar mengajar adalah sebagai berikut,

1) Daya serap terhadap bahan pengajaran yang diajarkan mencapai prestasi tinggi, baik secara individual maupun kelompok.

2) Perilaku yang digariskan dalam tujuan pengajaran/instruksional khusus (TIK) telah dicapai oleh siswa, baik secara individual maupun kelompok.

Berdasarkan uraian diatas, maka indikator yang banyak dipakai sebagai tolak ukur untuk hasil belajar siswa adalah daya serap dan kemampuan siswa dalam menuntaskan setiap kompetensi dasar yang dirumuskan dalam rencana pembelajaran yang diukur berdasarkan nilai KKM yaitu 75 .

Hasil belajar diartikan sebagai kemampuan yang dimiliki siswa setelah ia menerima pengalaman belajar. Untuk mengetahui sejauh mana keberhasilan siswa dalam mempelajari materipembelajaran, maka perlu adanya pengukuran hasil belajar yang diperoleh melalui tes, yang dinyatakan dalam bentuk angka dan nilai tertentu. Hasil belajar merupakan hasil dari suatu interaksi hasil belajar dan tindak mengajar. Dari sisi guru, tindak mengajar diakhiri dengan proses evaluasi hasil belajar. Dari sisi siswa, hasil belajar 
merupakan puncak proses belajar yang merupakan bukti dari usaha yang telah dilakukan.

\section{Pembelajaran Geografi}

Bagi makhluk hidup, belajar merupakan proses kegiatan yang sangat bermakna. Belajar tersebut tidak hanya dialami oleh manusia melainkan hewan juga mengalaminya. Namun demikian belajar pada diri hewan sangat dipengaruhi oleh naluri yang melekat pada mereka, sedangkan pada diri manusia, pengaruh naluri tadi direduksi oleh akal-pikiran yang berkembang dan dapat dikembangkan. Makna belajar pada diri manusia sangat luas sesuai dengan kondisi, situasi, tantangan, dan masalah yang dihadapi.

Menurut Gatot (2016), "Geografi berasal dari dua kata Geographica yang berarti Geo = Bumi dan Grafphica $=$ Penulisan. Geografi adalah ilmu tentang persamaan dan perbedaan fenomena geosfer dengan sudut pandang kewilayahan dan kelingkungan dalam konteks keruangan”. Sejak manusia lahir di dunia, manusia sangat bergantung pada alam lingkungannya. Manusia membutuhkan alam untuk dapat memenuhi kebutuhan hidupnya. Karena didorong kebutuhan hidupnya tersebut, manusia berusaha untuk memanfaatkan alam untuk memenuhi kebutuhan hidupnya. Inilah awal lahirnya studi geografi.

Menurut Bonawati (2013), “Geografi merupakan ilmu yang sama-sama mempelajari bumi. Karakteristik geografi sebagai ilmu nampak dari sasaran kajiannya yang khas disebut sebagai objek material dan objek formal. Selain itu, siswa dimotivasi secara aktif untuk menelaah bahwa kebudayaan dan pengalaman mempengaruhi persepsi manusia tentang tempat-tempat dan wilayah. Dengan demikian siswa diharapkan bangga akan warisan budaya dengan memiliki kepedulian kepada keadilan sosial, proses-proses demokratis dan kelestarian ekologis, yang pada gilirannya dapat mendorong siswa untuk meningkatkan kualitas kehidupan di lingkungannya pada masa kini dan masa depan".

Pembelajaran geografi merupakan pembelajaran yang berkaitan tentang segala sesuatu pada bumi baik Ilmu yang menelaah tentang bumi dan segala isi serta kaitan-kaitan yang masih berhubungan dengan bumi. Dalam mengusai konsep-konsep Geografi dan metode mengajar, guru Geografi juga harus menguasai teori-teori belajar agar apa yang disampaikan dapat dipahami dengan mudah oleh siswa. Sebelum memasuki pelajaran Geografi, siswa sudah memiliki pengetahuan dan pengalaman yang berhubungan dengan pengajaran Gegrafi. Pengetahuan dan pengalaman ini membentuk pra-konsep, terjadi prakonsep tersebut belum tentu benar kadang bertentangan dengan hasilnya. Di sinilah terjadi konflik kognitif, barulah konsep lama dan baru dipadukan maka untuk mewujudkan pengajaran Geografi harus diperhatikan hal-hal di atas. Untuk itu penulis mengajukan penerapan metode resitasi berbasis ICT terhadap materi Pengetahuan Dasar Geografi yang lebih mukhtahir.

\section{METODOLOGI PENELITIAN}

Metode penelitian adalah cara ilmiah untuk mendapatkan data dengan tujuan dan kegunaan tertentu (Sugiyono, 2015). Pada penelitian ini digunakan metode penelitian Quasi Eksperiment Design. Penelitian eksperimen adalah penelitian yang dilakukan untuk mengetahui pengaruh pemberian suatu treatment atau perlakuan terhadap subjek penelitian. Jadi penelitian eksperimen dalam penelitian ini adalah kegiatan penelitian yang bertujuan untuk menilai pengaruh suatu perlakuan/tindakan/treatment terhadap tingkah laku siswa atau menguji hipotesis tentang ada-tidaknya pengaruh tindakan itu jika dibandingkan dengan tindakan lain.

Metode penelitian ini merupakan metode penelitian eksperimen yang bertujuan untuk mengetahui pengaruh penggunaan media pembelajaran resitasi berbasis ICT dalam pembelajaran geografi. Selain itu, juga untuk mendapatkan gambaran hasil belajar siswa kelas X IPS SMA Negeri 1 Palembang setelah belajar dengan menggunakan media pembelajaran resitasi berbasis ICT. Desain penelitian yang digunakan dalam desain ini adalah desain penelitian PosttestOnly Control Design. Desain ini terdapat dua kelompok yang dipilih karena pertibangan tertentu, kelompok pertama diberi perlakuan (X) dengan menggunakan metode Resitasi berbasis ICT dan kelompok yang lain tidak. Kelompok yang diberi 
perlakuan disebut eksperimen dan kelompok yang tidak diberi perlakuan disebut kontrol.

\section{HASIL DAN PEMBAHASAN}

Setelah dilakukan pengumpulan data, maka selanjutnya data akan dianalisis untuk membuktikan ada tidaknya pengaruh metode pembelajaran resitasi berbasis ICT (Information Communication Technology) terhadap hasil belajar geografi siswa kelas $X$ di SMA Negeri 1 Palembang tahun pelajaran 2018/2019. Dari hasil nilai Resitasi terdapat nilai terendah dan tertinggi, nilai terendah yaitu 55 dan nilai tertinggi 95 dengan jumlah 2650 dan rata-rata 75,71. Dari 35 siswa, 21 siswa mendapatkan hasil tuntas dan 14 siswa tidak tuntas.

Uji normalitas dilakukan untuk menguji apakah sampel berasal dari populasi yang berdistribusi normal atau tidak. Analisis statistik menggunakan uji Kolmogorov-Smirnov menggunakan SPSS 22. Data yang diperoleh dari nilai kelas eksperimen dan kelas kontrol siswa kelas X IPS 1 dan X IPS 3 seperti yang ditunjukkan tabel 4.13 di atas, terlihat bahwa nilai kelas eksperimen dan kelas kontrol memiliki taraf signifikansi lebih dari 0,05 (0,200>0,05) ini artinya data nilai kelas eksperimen dan kelas kontrol berdistribusi normal.

Uji homogenitas bertujuan untuk mengetahui apakah sampel berasal dari varians yang sama atau tidak dan membuktikan kesamaan varians kelompok yang membentuk sampel tersebut. Analisa yang digunakan untuk menguji kesamaan varians dalam penelitian ini menggunakan uji-F menggunakan Program SPSS versi 22, dasar pengambilan keputusan dari tes homogenitas ini yaitu jika nilai signifikansi lebih dari 0,05 maka distribusi data adalah homogen, begitu juga sebaliknya jika nilai signifikansi kurang dari 0,05 maka distribusi data adalah tidak homogen. Hasil uji homogenitas penelitian diketahui memiliki taraf signifikansi $(p)$ sebesar 0,189 artinya $p>0,05$. Maka dapat disimpulkan data nilai kelas eksperimen dan nilai kelas kontrol memiliki varians yang homogen.

Hasil analisis data diketahui bahwa nilai $t_{\text {hitung }}$ sebesar 6,374 dengan nilai signifikansi (2-tailed) sebesar 0,000. Kemudian nilai $t_{\text {hitung }}$ dibandingkan dengan $t_{\text {tabel }}$ pada taraf signifikansi $5 \%$ dari d. $b=(\mathrm{N}-$
1) $=(35-1)=34$, sehingga diperoleh $t_{\text {tabel }}$ sebesar 1,69. Hal ini menunjukkan bahwa nilai $t_{\text {hitung }}$ lebih besar daripada $t_{\text {tabel }} \quad(6,347>1,69)$. Apabila dibandingkan dengan nilai signifikansi (2-tailed) sebesar 0,000 lebih kecil dari signifikansi 0,05 $(0,000<0,05)$, maka hipotesis dalam penelitian ini dinyatakan diterima. Artinya terdapat pengaruh metode pembelajaran resitasi berbasis ICT (Information Communication Technology) terhadap hasil belajar geografi pada siswa kelas X IPS di SMA Negeri 1 Palembang dimana nilai rata-rata kelas eksperimen lebih besar dibandingkan kelas control.

Dengan demikian hipotesis alternatif (Ha) yang berbunyi terdapat pengaruh yang signifikan dari penerapan metode pembelajaran resitasi berbasis ICT (Information Communication Technology) terhadap hasil belajar geografi pada siswa kelas X IPS di SMA Negeri 1 Palembang diterima. Ini berarti hipotesis nol (Ho) yang berbunyi "tidak ada pengaruh yang signifikan dari penerapan metode pembelajaran resitasi berbasis ICT (Information Communication Technology) terhadap hasil belajar geografi pada siswa kelas X IPS di SMA Negeri 1 Palembang” ditolak.

Penerapan metode pembelajaran resitasi berbasis ICT (Information Communication Technology) merupakan penggunaan metode pembelajaran yang seharusnya diterapkan oleh semua guru di SMA Negeri 1 Palembang, karena metode ini mampu memberikan pengaruh yang signifikan terhadap hasil belajar siswa. Sebelum menerapkan metode pembelajaran resitasi berbasis ICT (Information Communication Technology) tersebut peneliti mengumpulkan dokumentasi siswa kelas eksperimen dan kelas kontrol apakah sampel yang diambil secara Random ini memiliki kesesuaian dengan tingkat kecerdasan siswa dari kedua kelas tersebut.

Dalam penelitian pengaruh metode pembelajaran resitasi berbasis ICT (Information Communication Technology) terhadap hasil belajar geografi pada siswa kelas $\mathrm{X}$ di SMA Negeri 1 Palembang, peneliti menggunakan dua kelas sebagai kelas eksperimen yaitu kelas X IPS 1 yang berjumlah 35 orang siswa dan kelas X IPS 3 sebagai kelas kontrol berjumlah 35 siswa. Berdasarkan hasil penelitian diperoleh data hasil dokumentasi ternyata 
kelas X IPS 1 dan kelas X IPS 3 memiliki nilai yang homogen sehingga sangat tepat untuk dijadikan sampel penelitian.

Pada penelitian di kelompok eksperimen, diadakan pertemuan sebanyak tiga kali, dimana pertemuan pertama peneliti melakukan kegiatan pembelajaran di kelas eksperimen maupun kontrol sebanyak tiga indikator, dilanjutkan dengan pertemuan kedua dan kegiatan pembelajaran melanjutkan tiga indikator berikutnya. Dalam proses kegiatan pembelajaran kelas eksperimen diberikan metode pembelajaran resitasi berbasis ICT (Information Communication Technology) sedangkan kelas kontrol tidak diberikan metode pembelajaran resitasi berbasis ICT (Information Communication Technology) dan hanya belajar secara konvensional. Setelah minggu ketiga (pertemuan ketiga) diadakan tes akhir hasil belajar pada siswa untuk melihat pengaruh dari metode pembelajaran resitasi berbasis ICT (Information Communication Technology) terhadap hasil belajar geografi pada siswa kelas X IPS 1 dan X IPS 3 di SMA Negeri 1 Palembang.

Setelah diperoleh data hasil tes siswa kelas eksperimen maupun kelas kontrol, maka peneliti melakukan analisis data tes tersebut. Analisis data dilakukan dengan menggunakan Uji-t yang terdiri dari uji normalitas data dan uji homogenitas data. Uji normalitas data dilakukan untuk mengetahui normal atau tidaknya suatu peyebaran data, kemudian uji homogenitas data diperlukan untuk membuktikan persamaan variansi kelompok sampel.

Analisis data diketahui bahwa nilai thitung sebesar 6,374 dengan nilai signifikansi (2-tailed) sebesar 0,000 . Kemudian nilai $t_{\text {hitung }}$ dibandingkan dengan $t_{\text {tabel }}$ pada taraf signifikansi $5 \%$ dari d. $b=(\mathrm{N}-$ $1)=(35-1)=34$, sehingga diperoleh $t_{\text {tabel }}$ sebesar 1,69. Hal ini menunjukkan bahwa nilai $t_{\text {hitung lebih }}$ besar daripada $t_{\text {tabel }}(6,347>1,69)$. Apabila dibandingkan dengan nilai signifikansi (2-tailed) sebesar 0,000 lebih kecil dari signifikansi 0,05 $(0,000<0,05)$, maka hipotesis dalam penelitian ini dinyatakan diterima. Artinya terdapat pengaruh metode pembelajaran resitasi berbasis ICT (Information Communication Technology) terhadap hasil belajar geografi pada siswa kelas X IPS di SMA Negeri 1 Palembang dimana nilai rata-rata kelas eksperimen lebih besar dibandingkan kelas Kontrol. Dari hasil tersebut dapat disimpulkan bahwa, sampel berasal dari populasi yang sama. Jadi, data penelitian yang berasal dari kelas eksperimen maupun kelas kontrol mengikuti distribusi normal dan homogen.

Hasil penelitian Wibisono, (2017) dengan judul Efektivitas Penggunaan Grup Sosial Media Whatsapp sebagai Media Edukasi Penanganan Pertama Cedera Muskuloskeletal pada Pelatih Sepak Bola, menunjukkan bahwa; 1. Pemberian intervensi berupa video yang diberikan melalui whatsapp membantu peningkatan nilai atau skor pelatih mengenai penanganan pertama cedera musculoskeletal; 2. Terdapat pengaruh yang signifikan intervensi video melalui grup social media whatsapp dengan $\mathrm{t}$ hitung adalah -4.699 dengan probabilitas $0,000<0,05 ; 3$. Pemberian intervensi video melalui whatsapp dinilai mampu meningkatkan pengetahuan pelatih.

Hasil ini sejalan dengan hasil penelitian yang dilakukan oleh Humairoh, 2011(Pengaruh Metode Pemberian Tugas dan Resitasi Terhadap Hasil Belajar IPS Terpadu (Geografi) Siswa pada Kelas VII di MTs. Daarul Hikmah Pamulang). Hasil penelitian diperoleh nilai regresi " $\mathrm{r}$ " tabel $=0,419$. Jika dilihat dari pada taraf signifikansi 5\% $(0,419>0,349)$ sehingga disimpulkan bahwa pengaruh metode pemberian tugas dan resitasi memberikan kontribusi positif terhadap hasil belajar siswa. Jadi, dapat disimpulkan bahwa penggunaan metode Resitasi berbasis Information Communication Technology (ICT) berpengaruh signifikan terhadap hasil belajar geografi siswa kelas X IPS pada pokok bahasan pengetahuan dasar geografi.

Penelitian yang dilakukan oleh setiap peneliti tentu memiliki temuan-temuan yang berbeda, sedangkan temuan yang di temukan oleh peneliti adanya kelebihan dan kelemahan. Adapun, kelebihan pada saat penelitian yaitu

1. Dapat merangsang siswa dalam melakukan aktivitas belajar individual ataupun kelompok;

2. Dapat mengembangkan kemandirian siswa;

3. Dapat mengembangkan kreatifitas siswa;

4. Dapat meningkatkan keinginan belajar;

5. Menggunakan media sosial sebagai alat untuk melakukan proses belajar mengajar; 
6. Menggali informasi melalui ICT (information communication technology);

7. Memiliki sarana dan prasarana yang memadai, karena tidak semua sekolah memiliki sarana dan prasarana tersebut.

Sedangkan kelemahan peneliti yaitu

1. Sulitnya mengontrol siswa saat diskusi online;

2. Saat peneliti memberi penugasan melalui grup Whatsapp, sebagian siswa hanya menerima saja tetapi tidak merespon dengan cepat;

3. Siswa kurang memanfaatkan fasilitas yang tersedia. Untuk peneliti lain hendaknya bisa mengembangkan lagi metode pembelajaran resitasi berbasis ICT (information communication technology) agar siswa dapat menggunakan sarana dan prasarana yang ada, sehingga hasil belajar geografi siswa dapat meningkat.

\section{SIMPULAN}

Berdasarkan hasil penelitian maka dapat disimpulkan bahwa hasil belajar geografi siswa kelas yang diajar dengan menggunakan metode pembelajaran resitasi berbasis ICT lebih tinggi dari hasil belajar geografi siswa yang diajar dengan metode klasikal. Dengan kata lain, dapat disimpulkan terdapat pengaruh dari penerapan pembelajaran metode resitasi berbasis ICT terhadap hasil belajar geografi siswa.

\section{DAFTAR PUSTAKA}

Ariyani, Fina. (2010). Pengaruh Pembelajaran Berbantukan Media Online Facebook Terhadap Hasil Belajar Fisika dalam Konsen Termodinamika. UIN Syarif Hidayatullah, Jakarta.

Banowati. (2013). Geografi Sosial. Yogyakarta : Ombak

Djamarah \& Zain. (2014). Strategi belajar mengajar. Jakarta : Renika cipta.

Gatot Harmanto. (2016). Geografi Untuk Siswa SMA/MA Kelas X Kelompok Peminatan IlmuIlmu Sosial. Bandung :Yrama Widya.

Humairoh. (2011). Pengaruh Metode Pemberian Tugas dan Resitasi terhadap Hasil Belajar IPS Terpadu (Geografi) Siswa pada Kelas VII di MTs Daarul Hikmah Pamulang. Skripsi. http://repository.uinjkt.ac.id/dspace/bitstream/ 123456789/2950/1/UMI\%20HUMAIROHFITK.pdf. Diakses 25 Juni 2018

Sugiyono. (2016). Statistika untuk Penelitian. Bandung : Alfabeta

Suryani, Nunuk. (2015). Pengembangan ICT dalam Pembelajaran. Universitas Negeri Semarang, Semarang.

Wibisono. (2017). Efektivitas Penggunaan Grup Sosial Media Whatsapp sebagai Media Edukasi Penanganan Pertama Cedera Muskuloskeletal pada Pelatih Sepak Bola. Skripsi. https://eprints.uny.ac.id/53575/. Diakses 25 Juni 2018 